\title{
Gambaran Faktor-faktor yang Mempengaruhi Minat Peternakan dalam Budidaya Ternak Kelinci Di Kecamatan Bluluk Kabupaten Lamongan
}

\author{
Rabbit Livestock Cultivation Influence Factors Analisys in Bluluk Subdistrict Lamongan Regency \\ Iswandi $^{1}$, Ir. Mufid Dahlan, MMA ${ }^{2}$, Drh. Dyah Wahyuning, S.Pt ${ }^{3}$ \\ ${ }^{1}$ Mahasiswa Fakultas Peternakan \\ ${ }^{2}$ Dosen Pembimbing Utama \\ ${ }^{3}$ Dosen Pembimbing Pendamping \\ Program Studi Peternakan \\ Fakultas Peternakan, Universitas Islam Lamongan (UNISLA)
}

\section{RINGKASAN}

Pengumpulan data penelitian dilaksanakan tanggal 25 Mei 2016 sampai 25 Juni 2016 di Kecamatan Bluluk, Kabupaten Lamongan.Sampel ditentukan sebanyak 17 peternak kelinci. Tujuan penelitian ini adalah Mengetahui gambaran faktor-faktor yang mempengaruhi minat peternak dalam budidaya ternak kelinci di Kecamatan Bluluk Kabupaten Lamongan. Metode yang digunakan adalah survey yakni pengamatan langsung ke lapangan untuk mengetahui obyek yang akan di teliti. Analisis deskriptif, dan menggunakan model pengelompokan, penyederhanaan, serta penyajian seperti table distribusi frekuensi dan pengukuran dengan menggunakann skala likerts. Hasil penelitian ini menunjukkan bahwa berdasarkan analisis penelitian yang dilakukan bahwa faktor-faktor yang mempengaruhi minat budidaya ternak kelinci dengan menggunakan analisis deskripsi. Sehingga di ketahui factor produksi 72,93 pakan dan kandang 73,16 pemasaran 72,23 aspeksosial 67,99. Di peroleh nilai rata-rata tertinggi pada factor pakan dan kandang 73,16 dengan rage antara 60-80\%. Diperlukan penelitian selanjutnya untuk menganalisis faktor-faktor yang mempengaruhi minat budidaya ternak kelinci. Sehingga dapat mengetahui faktor-faktor yang lainnya baik faktor internal maupun external.

\section{ABSTRACT}

The research file accumulation implemented from in Bluluk subdistrick, Lamongan regency. The aim of the research is know the factors of rabbit livestock cultivation interest in Bluluk subdistrick, Lamongan regeny. The research used survey method that direct outdoor observation to know the object that will scrutinized. Descriptibe analysis used grouping model, simplification, as well as reserved like frequency distribution table and measuring used likerts scale. The result of this research indicated based on research analysis that rabbit livestock cultivation influence factors used descriptive analysis. Until production factors is known that 72,93. woof and 73,16 stable 72,23 marketing 67,99 sosial aspect. Result obtained woof and stable factor on higest average between $60-80 \%$ rage. Needed next research to analyzing rabbit livestock cultivation influence factors. Till known other factors like internal or external factors.

\section{PENDAHULUAN}

Di Indonesia ternak kelinci mempunyai kemampuan kompetitif untuk bersaing dengan sumber daging lain dalam memenuhi kebutuhan hidup manusia (kebutuhan gizi) dan merupakan alternatif penyedia daging yang perludipertimbangkan di masa datang. Daging kelinci merupakan salah satu daging yang berkualitas baik dan layak dikonsumsi oleh berbagai kelas lapisan masyarakat. Bahkan dibandingkan dengan kondisi daging ayam dilihat dari segi aroma, warna daging dan dalam berbagai bentuk masakan tidak ditemukan perbedaan yang nyata (Diwyanto, et all., 1985).

Usaha peternakan mempunyai prospek untuk dikembangkan karena tingginya permintaan akan produk peternakan. Usaha peternakan juga member keuntungan yang cukup tinggi dan menjadi sumber pendapatan bagi banyak masyarakat dari segi manfaat. Peternakan merupakan salah satu bidang usaha yang menghasilkan bahan pangan sumber protein hewani. Bahan pangan sumber protein hewani diantaranya adalah: telur, susu, dan 
daging. Salah satu cara untuk memenuhi kebutuhan daging bagi masyarakat adalah dengan berternak kelinci, karena kelinci mempunyai potensi untuk dikembangkan sebagai ternak penghasil daging.

Daging kelinci mempunyai struktur yang lebih halus dibandingkan dengan daging sapi, dagingdomba, dan daging kambing.Kandungan protein daging kelinci sebesar 20,7\%. Sedangkan daging sapi $19,3 \%$ dan daging domba $18,7 \%$. Kadar lemak daging kelinci lebih rendah (hanya 6,2\%). Di bandingkan lemak daging sapi yang mencapai $18,3 \%$ dan lemak daging domba $17,5 \%$ (Rukman, 2005).

Beberapa manfaat yang diperoleh dari beternak kelinci salah satunya dari segi keuntungan ekonomi yang diperoleh. Pada peternakan kelinci skala kecil dan menengah mempunyai keuntungan antara lain: modal usaha yang relative kecil, pakan sangat mudah diperoleh dan tidak tergantung pada pakan pabrik. Potensi utama ternak kelinci dalam mewujudkan suatu agribisnis adalah kemampuannya untuk tumbuh dan berkembangbiak dengan cepat, baik melalui pola usaha skala rumah tangga maupun industri yang dapat menghasilkan berbagai ragam produk bermutu yang dibutuhkan pasar. Hanya saja memang ternak ini mudah stress sehingga dapat meningkatkan kematian, terutama pada sapihan baru (Fatmawati, 2011).

Kelinci memiliki beberapa keunggulan yaitu menghasilkan daging yang berkualitas tinggi dengan kadar lemak yang rendah, tidak membutuhkan areal yang luas dalam pemeliharaan, dapat memanfaatkan bahan pakan dari berbagai jenis hijauan, sisa dapur dan hasil sampingan produk pertanian, hasil sampingan (kulit/bulu, kepala, kaki dan ekor serta kotorannya) dapat dimanfaatkan untuk berbagai keperluan, biaya produksi relatif murah, pemeliharannya mudah, dan dapat melahirkan anak 4 - 6 kali setiap tahunnya dan menghasilkan 4-12 anak setiap kelahiran (Kartadisastra, 1994).

Kecamatan Bluluk adalah salah satu Kecamatan yang ada di Kabupaten Lamongan bagian selatan yang berada di dataran tinggi memiliki dua musim hujan dan kemarau, di sana bahan pakan ternak sangat melimpah, hijauan dan leguminosa, sehingga cocok digunakan sebagai sentral peternakan. Sebagian masyarakat berbudidaya ternak kelinci. Jika dibandingkan dengan Kecamatan lain di Kabupaten Lamongan, Kecamatan Bluluk lebih banyak jumlah populasi kelincinya, sehingga menjadi salah satu tempat dalam penelitian ini dengan judul Gambaran Faktor-faktor Yang Mempengaruhi minat peternak dalam budidaya Ternak Kelinci Di Kecamatan Bluluk Kabupaten Lamongan.

\section{MATERI DAN METODE}

Materi yang di gunakan dalam penelitian ini adalah semua populasi kelinci sebagai sampel sebanyak 17 peternak kelinci.

Metode penelitian yang digunakan adalah jenis metode survei.Seperti yang disampaikan oleh Arikunto (2006) bahwa, survey adalah pengamatan langsung kelapangan untuk mengetahui obyek yang akan diteliti. Data yang digunakan dalam penelitihan adalah data primer dan sekunder.

Data primer adalah data yang diperoleh dari responden penelitian secara langsung.Yaitu hasil wawancara dan dokumen yang telah disusun sesuai kebutuhan dilapangan.Sebagaimana yang disampaikan oleh Noor (2011) bahwa, wawancara merupakan salah satu teknik pengumpulan data yang dilakukan dengan berhadapan langsung dengan narasumber tetapi dapat juga diberikan daftar pertanyaaan dahulu untuk dijawab pada kesempatan lain. Sedangkan data sekunder adalah data yang diperoleh dari sumber lain selain lokasi penelitihan, penulis disini mengambil data sekunder dari literatur yang berkaitan dengan permasalahan.

\section{JENIS PENELITIAN}

Jenis penelitian ini adalah deskriptif yaitu menggambarkan atau menguraikan variable penelitian yaitu gambaran faktor-faktor yang mempengaruhi minat peternak dalam budidaya ternak kelinci, produksi usaha ternak kelinci dan pemasaran usaha ternak kelinci di Kecamatan Bluluk Kabupaten Lamongan.

\section{ANALISIS DATA}

Analisa data yang digunakan pada penelitian ini adalah data mengenai gambaran 
faktor-faktor yang mempengaruhi minat peternak dalam budidaya ternk kelinci dengan menggunakan analisis statistic deskriptif, dan menggunakan model pengelompokan, penyederhanaan, serta penyajian seperti table distribusi frekuensi dan pengukuran dengan menggunakan skala likerts.

Menurut Ridwan (2008), bahwa skala likert digunakan untuk mengukur sikap, pendapat, persepsi seseorang atau sekelompok seseorang atau sekelompok tentang kejadian gejala sosial. Dengan menggunakan skala likert maka variabel yang akan diukur dijabarkan menjadi indikator-indikator yang dapat diukur, dapat berupa menjadi pernyataan atau pertanyaan yang selanjutnya dikategorikan kedalam skor sebagaiberikut:

Sangat baik $=$ Skor 5

Baik = Skor 4

Cukup baik $=$ Skor 3

Kurang baik $=$ Skor2

Tidak baik $=$ Skor 1

\section{HASIL DAN PEMBAHASAN}

Analisis faktor-faktor yang mempengaruhi minat budidaya ternak kelinci di Kecamatan Bluluk, Kabupaten Lamongan

Minat masyarakat adalah suatu keinginan seseorang terhadap objek tertentu berupa tanggapan yang diberikan oleh masyarakat mengenai peternakan kelinci, dimana peternakan kelinci yang berada di Kecamatan Bluluk Kabupaten Lamongan menurut masyarakat yang minat berternak kelinci masih jarang. Adapun tingkat minat masyarakat terhadap budidaya ternak kelinci di Kecamatan Bluluk, Kabupaten Lamongan di pengaruhi beberapa faktor dapat dilihat pada indikator dari variabel penelitian ini adalah :

A. Aspek produksi dan reproduksi kelinci

B. Pakan dan Perkandangan

C. Pemasaran

D. Aspek sosial

\subsubsection{Produksi dan Reproduksi}

Budidaya dapat kita lakukan dengan cara memelihara kelinci atau dengan kata lain membudidayakan. Kelinci dapat berkembangbiak secara alami, artinya tidak adanya campur tangan manusia. Hasil perkembangan biakan secara alami ini kemungkinan sebagaian besar anak-anaknya tidak bisa hidup sampai dewasa. Dengan alasan anak-anaknya bisa dimakan binatang lain maupun diburu oleh manusia. Sehingga anakanak kelinci sebagaian besar tidak bisa hidup sampai dewasa.Apabila perkembangan secara alami ini tidak diperlukan oleh manusia, atau tidak adanya campur tangan manusia, maka populasi kelinci semakin berkurang. Bila populasi tiap tahunnya berkurang ini dimungkinkan perkembangan populasi kelinci beberapa tahun mendatang akan punah.

Adapun analisis faktor-faktor yang mempengaruhi minat budidaya ternak kelinci di Kecamatan Bluluk, Kabupaten Lamongan.

Tabel 5. Persepsi Responden Mengenai Minat Budidaya dengan Sub Variabel Produksi di Kecamatan Bluluk Kabupaten Lamongan.

\begin{tabular}{|c|c|c|}
\hline $\mathrm{o}$ & Soal kuisoner & $\begin{array}{r}\text { Per } \\
\text { sentase }(\%)\end{array}$ \\
\hline & $\begin{array}{l}\text { Bagaimana menurut } \\
\text { Saudara kelinci mudah di } \\
\text { budidayakan? }\end{array}$ & 74,11 \\
\hline & $\begin{array}{l}\text { Bagaimanakah menurut } \\
\text { Saudara apakah seekor } \\
\text { induk kelinci r bisa } \\
\text { melahirkan anak dalam } \\
\text { jumlah banyak? }\end{array}$ & 72,94 \\
\hline & $\begin{array}{l}\text { Bagaimanakah menurut } \\
\text { Saudara apakah masa } \\
\text { kebuntingan kelinci di } \\
\text { daerah ini tergolong } \\
\text { sangat cepat? }\end{array}$ & 76,47 \\
\hline & $\begin{array}{l}\text { Bagaimanakah menurut } \\
\text { Saudara apakah kelinci } \\
\text { jantan bisa mengaini } \\
\text { kelinci betina dalam } \\
\text { jumlah banyak? }\end{array}$ & 71,76 \\
\hline & $\begin{array}{l}\text { Apakah kelinci betina } \\
\text { memiliki masa dewasa } \\
\text { kelamin lebih cepat dari } \\
\text { pada kelinci betina? }\end{array}$ & 69,41 \\
\hline & Rata-rata & 72,93 \\
\hline
\end{tabular}

Sumber : Data Primer Setelah Diolah, (2016)

Berdasarkan Tabel 5.lampiran 7. Hasil perhitungan persentase menunjukan persepsi responden terhadap kelinci mudah di budidayakan diperoleh total skor 74,11 yang berada dalam kategori tinggi dalam interval setuju. tinggi skor tersebut disebabkan karena kelinci mudah di budidayakan di Kecamatan 
Bluluk. Hal ini sesuai dengan pendapat (Sumadji, 2006) Budidaya kelinci pada dasarnya tidak terlalu sulit, namun pembudidaya sebaiknya dapat mengetahui jenis-jenis kelinci yang cocok dan dapat dibudidayakan serta dapat hidup di wilayah Indonesia ini. Kelinci sebenarnya merupakan hewan yang dapat hidup dengan mudah di wilayah kita. Hewan ini mempunyai tingkat hidup yang sanggat tinggi dan dapat berkembang dengan baik dan cepat. (Sumadji, 2006).

Hasil perhitungan persentase menunjukkan persepsi responden terhadap seekor kelinci bisa melahirkan anak dalam jumlah banyak diperoleh total skor 72,92 yang berada dalam kategori tinggi dalam interval setuju. Tingginya skor tersebut disebabkan kelinci yang dibudidayakan di Kecamatan Bluluk mampu melahirkan anak dalam jumlah banyak. Hal ini sesuai dengan pendapat (Sumoprastowo (1993); Sarwono, 2002) Kelinci (Oriyctolaguscuniculus) adalah fauna yang tergolong dalam kelas mamalia yang mudah di pelihara,cepat berkembang biak,tidak memerlukan biaya besar dalam pemeliharaan,mampu menghasilkan anak 4-6 kali setiap tahun,dengan jumlah anak 4-12 ekor anak perkelahiran.

Hasil perhitungan persentase menunjukan persepsi responden terhadap masa kebuntingan kelinci di daerah ini tergolong sangat cepat diperoleh total skor 76,47 yang berada dalam kategori tinggi dalam interval setuju. Tingginya skor tersebut disebabkan karena kelinci memiliki masa kebuntingan yang pendek.Lama kebuntingan pada ternak kelinci berkisar antar 28-35 hari. Dengan rata-rata kebuntingan selama 31 hari. Lama kebuntingan di pengaruhi oleh beberapa faktor seperti; bangsa/strain, umur induk, sifat-sifat khusus pewarisan, jenis kelamin anak yang di kandung, dimana jika anak yang di kandung jantan maka lama kebuntingan lebih lama satu hari dari anak betina (Partodihardjo; 1980);

$$
\text { Hasil perhitungan persentase }
$$

menunjukan persepsi responden terhadap kelinci jantan bisa mengawini kelinci betina dalam jumlah banyak diperoleh total skor 71,76 yang berada dalam kategori tinggi dalam interval setuju. Tingginya skor tersebut di karenakan kelinci jantan mampu mengawini betina dalam jumlah banyak. Hal ini sesuai pendapat (Sumoprastowo, (1993). Seekor pejantan yang telah dewasa dapat melayani betina 10 ekor, tetapi pada umumnya 5 ekor betina dikawinkan dengan satu pejantan dalam satu kandang koloni. Jika jumlah betina lebih banyak sedangkan pejantan tetap maka persentase kebuntingan akan menurun. Sebaliknya jika jumlah betina terlalu sedikit maka tidak ekonomis. Penggunaan pejantan dalam perkawinan tidak boleh lebih tiga kali dalam satu minggu. Pejantan yang di gunakan dua kali dalam satu minggu dengan mengawini dua ekor betina menunjukkan hasil yang cukup memuaskan. Sedangkan menurut (Hardjopranjoto; 1995). Pemakaian pejantan yang berlebihan untuk mengawini betina dapat mengakibatkan penurunan kemampuanpejantan, dimana libido pejantan di pengaruhi beberapa faktor, seperti; faktor genetik, umur dan faktor lingkungan.

\section{Hasil perhitungan persentase} menunjukan persepsi responden terhadap kelinci betina memiliki masa dewasa kelamin lebih cepat dari pada kelinci betina di peroleh skor 69,41yang berada dalam kategori tinggi dalam interval setuju. Tingginya skor tersebut di karenakan betina mencapai dewasa kelamin lebih cepat dari pada jantan. Kelinci jantan mencapai dewasa kelamin pada umur 6 bulan, sedangkan betina pada umur 4-5 bulan. Kelinci tipe kecil dewasa kelamin antara 3-4 bulan. Tipe sedang 5-6 bulan dan tipe besar 7-8 bulan. Cepat lambatnya dewasa kelamin dipengaruhi oleh faktor individu, lokasi peternakan, pakan yang diberikan dan system perkandangan (Whendrato dan Madyana, 1999).

\subsubsection{Pakan dan Kandang}

Sebagaimana halnya manusia, agar pertumbuhannya normal kelinci membutuhkan zat-zat makanan, seperti karbohidrat, lemak, protein, mineral, vitamin, dan air. Di habita aslinya, kelinci memakan rumput-rumputan, biji-bijian, dan dedaunan. Sistem perkandangan yang di gunakan harus memperhatikan kemudahan berkerja, penghematan waktu, dan tenaga.

Tabel 6.Persepsi Responden Mengenai Minat Budidaya dengan Sub Variabel pakan 
dankandang di Kecamatan Bluluk Kabupaten Lamongan.

\begin{tabular}{|c|c|c|}
\hline $\mathrm{O}$ & Soal kuisoner & $(\%)$ \\
\hline & 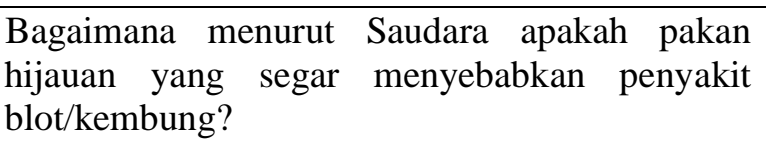 & 67,05 \\
\hline & $\begin{array}{l}\text { Bagaimana menurut Saudara terhadap } \\
\text { ketersediaan pakan hijauan di lokasi anda } \\
\text { apakah sangat melimpah? }\end{array}$ & 75,29 \\
\hline & $\begin{array}{l}\text { Bagaimanakah menurut Saudara terhadap biaya } \\
\text { pakan dalam ternak kelinci apakah tergolong } \\
\text { murah? }\end{array}$ & 80 \\
\hline & $\begin{array}{l}\text { Apakah kandang sempit bisa di gunakan dalam } \\
\text { berternak kelinci? }\end{array}$ & 70,58 \\
\hline & $\begin{array}{l}\text { Bagaimana menurut saudara apakah lahan yang } \\
\text { sempit bisa di gunakan dalam berternak kelinci? }\end{array}$ & 72,91 \\
\hline & Rata-rata & 73,16 \\
\hline
\end{tabular}

Sumber : Data Primer Setelah Diolah, (2016)

Berdasarkan Tabel 6. Lampiran 7. Hasil perhitungan persentase menunjukan bahwa persepsi responden terhadap pakan hijauan yang segar menyebabkan penyakit blot/kembung diperoleh total skor 67,05 yang berada dalam katagori tinggi dalam sub variable pakan dan kandangdengn interval setuju. sebagian masyarakat yang berternak kelinci di Kecamatan Bluluk setuju bahwa hijauan segar berpengaruh terhadap penyakit dalam budidaya ternak kelinci. Hal ini sesuai pendapat (Hustamin,2006) Pakan hijauan segar di antaranya berupa rumput lapangan, daun turi, daun lamtoro, daun kembang sepatu, daun kacang panjang, daun ubi jalar,daun kacang tanah, daun papaya. Limbah sayuran seperti selada, kangkung, sawi, wortel, kola. Pakan hijauan sebaiknya di berikan secukupnya setelah dilayukan. Pelayuan ini bertujuan mengurangi kadar air yang terkandung di dalamnya. Jika tidak dilayukan, urine kelinci bisa berbau menyengat, perutnya kembung, mencret gatal-gatal dan scabies, bahkan bisa menyebabkan kematian akibat mencret.

Hasil perhitungan persentase menunjukan bahwa persepsi responden terhadapketersediaan pakan hijauan di lokasi anda apakah sangat melimpah diperoleh total skor 75,29 yang berada dalam katagori tinggi dalam sub variable pakan dan kandangdengn interval setuju. sebagian masyarakat yang berternak kelinci di Kecamatan Bluluk setuju bahwa pakanhijauan sangat melimpah.Hal ini sesuai pendapat (Hustamin,2006). Pakan hijauan segar di antaranya berupa rumput lapangan, daun turi, daun lamtoro, daun kembang sepatu, daun kacang panjang, daun ubi jalar,daun kacang tanah, daun papaya. Limbah sayuran seperti selada, kangkung, sawi, wortel, kola. Pakan hijauan sebaiknya di berikan secukupnya setelah dilayukan. Pelayuan ini bertujuan mengurangi kadar air yang terkandung di dalamnya.

Hasil perhitungan persentase menunjukan bahwa persepsi responden terhadap biaya pakan apakah tergolong murahdiperoleh total skor 80 yang berada dalam katagori tinggi dalam sub variable pakan dan kandangdengn interval setuju. sebagian masyarakat yang berternak kelinci di Kecamatan Bluluk setuju bahwa biaya pakan tergolong murah karena bisa mencari di sekitar rumah.Hal ini sesuai pendapat(Hustamin,2006)Sebagaimana halnya manusia, agar pertumbuhannya normal kelinci membutuhkan zat-zat makanan, seperti karbohidrat, lemak, protein, mineral, vitamin, dan air. Di habitat aslinya, kelinci memakan rumput-rumputan, biji-bijian,dan dedaunan.Karenanya,kelinci yang dipelihara harus mendapatkan pakan sesuai dengan kebutuhannya. Prinsipnya mudah didapat, bernilai ekonomis relatif rendah, dan mengandung zat makanan yang sesuai dengan kebutuhan kelinci.

Hasil perhitungan persentase menunjukan bahwa persepsi responden terhadap kandang sempit pakah bisa di gunakan dalam berternak kelinci diperoleh total skor 70,58 yang berada dalam katagori tinggi dalam sub variable pakan dan kandangdengn interval setuju. sebagian masyarakat yang berternak kelinci di Kecamatan Bluluk setuju bahwa kandang baterai yang mereka gunakan dalam berternak kelinci dengan ukuran kecil.Hal ini sesuai pendapat(Hustamin Rudy,2006) Setiap kandang diisi oleh satu ekor kelinci. Jika di isi kelinci betina kandang baterai di gunakan untuk melahirkan dan mengasuh anaknya. jika di isi pejantan kandang ini di gunakan untuk mengawinkan dan bisa juga di gunakan untuk anakan.

Hasil perhitungan persentase menunjukan bahwa persepsi responden terhadap 
lahan yang sempit bisa di gunakan berternak kelinci diperoleh total skor 72,94 yang berada dalam katagori tinggi dalam sub variable pakan dan kandangdengn interval setuju. sebagian masyarakat yang berternak kelinci di Kecamatan Bluluk setuju bahwa lahan yang sempit bisa di gunakan untuk berternak kelinci karena mereka mengunakan lahan atau pekarangan di sekeliling rumahnya.Hal ini sesuai pendapat(Hustamin Rudy,2006)Kandang pangung berada di atas tiang setinggi 60-100 cm lantainya bisa di buat dari bambu dan ram kawat dengan lubanglubang sekitar $2 \mathrm{~cm}$, sehingga kotoran bisa langsung ke bawah.Syarat utama untuk membangun kandang adalah dekat dengan sumber air, berada di lokasi yang sejuk (temperature 15-20 C), kelembaban 60-90\%, serta jauh dari berbagai ganguan dan predator.

\subsubsection{Pemasaran}

Produk peternakan merupakan salah satu produk pangan yang mempunyai peranan sangat penting dan cocok untuk pemenuhan gizi masyarakat. Telur, daging, susu adalah contoh produk peternakan yang mudah dijumpai dalam kehidupan sehari-hari, ini dikarenakan nilai beli konsumenakan produk peternakan sangat tinggi.

Tabel 7. Persepsi Responden Mengenai Minat Budidaya dengan Sub Variabel pemasaran di Kecamatan Bluluk Kabupaten Lamongan.

\begin{tabular}{|l|l|r|}
\hline \multicolumn{1}{|c|}{ Soal kuisoner } & $(\%)$ \\
\hline & $\begin{array}{l}\text { Apakah berternak kelinci bisa } \\
\text { digunakaan sebagai usaha? }\end{array}$ & 75,29 \\
$\begin{array}{l}\text { Apakah menurut anda pemasaran } \\
\text { kelinci sangat mudah? } \\
\text { Apakah ternak kelinci bisa di jadikan } \\
\text { sebagai penghasil daging dan kotoran } \\
\text { kelinci dapat digunakan sebagai } \\
\text { sebagai pupuk organik yang terbaik? }\end{array}$ & 69,41 \\
$\begin{array}{l}\text { Apakah ternak kelinci memiliki } \\
\text { peluang usaha yang baik ke depan? } \\
\text { Apakah dengan berternak kelinci } \\
\text { dapat membantu ekonomi Anda? }\end{array}$ & 71,76 \\
\hline \multicolumn{2}{|c|}{ Rata-rata } & 65,88 \\
\hline
\end{tabular}

Sumber : Data Primer Setelah Diolah, (2016)

Berdasarkan Tabel 7. Lampiran

7. Hasil perhitungan persentase menunjukan bahwa persepsi responden terhadap ternak kelinci bisa di gunakan sebagai usahadiperoleh total skor 75,29 yang berada dalam katagori tinggi dalam sub variable pemasaran dengn interval setuju. sebagian masyarakat yang berternak kelinci di Kecamatan Bluluk setuju bahwa ternak kelinci bisa di jadikan usaha sampingan dan utama kaena bisa membantu ekonomi. Hal ini sesuai pendapat (Sumadji, 2006) Budidaya kelinci ini merupakan pilihan yang lain untuk menambah penghasilan maupun dapat membuka lapangan pekerjaan baru. Budidaya kelinci pada dasarnya tidak terlalu sulit, namun pembudidaya sebaiknya dapat mengetahui jenis-jenis kelinci yang cocok dan dapat dibudidayakan serta dapat hidup di wilayah Indonesia ini. Kelinci sebenarnya merupakan hewan yang dapat hidup dengan mudah di wilayah kita. Hewan ini mempunyai tingkat hidup yang sanggat tinggi dan dapat berkembang dengan baik dan cepat.

Hasil perhitungan persentase menunjukan bahwa persepsi responden terhadap pemasaran ternak kelinci mudahdiperoleh total skor 69,41 yang berada dalam katagori tinggi dalam sub variable pemasaran dengn interval setuju. sebagian masyarakat yang berternak kelinci di Kecamatan Bluluk setuju bahwa pemasaran kelinci mudah karena sudah ada pembeli yang siap datang ke kandang peternak. Nilai beli konsumen akan produk untuk di konsumsi dapat ditingkatkan dengan memberikan kepuasan kepada konsumen atas produk yang dihasilkan oleh produsen, karena kepuasan konsumen menjadi tolak ukur dari keberhasilan perusahaan dalam menghasilkan produk yang berkualitas dan yang diinginkan oleh konsumen. Strategi pemasaran dapat dicapai dengan tepat dan terbaik untuk diterapkan, salah satunya produsen dapat melihat dari faktor marketing mix atau pemasaran. Marketing mix menjadi hal yang penting karena merupakan salah satu pokok pertimbangan konsumen dalam melakukan keputusan pembelian suatu produk (Herawati,2013).

Hasil perhitungan persentase menunjukan bahwa persepsi responden terhadap ternak kelinci apakah bisa di gunakan sebagai penghasil daging dan pupuk organikdiperoleh total skor 78,82 yang berada dalam katagori tinggi dalam sub variable pemasaran dengn interval setuju. sebagian masyarakat yang 
berternak kelinci di Kecamatan Bluluk setuju bahwa hasil ternak kelinci yang di dapatkan berupa daging dan pupuk organic bisa. Hal ini sesuai pendapat (Kartadisastra, 1994).Kelinci memiliki beberapa keunggulan yaitu menghasilkan daging yang berkualitas tinggi dengan kadar lemak yang rendah, tidak membutuhkan areal yang luas dalam pemeliharaan, hasil sampingan (kulit/bulu, kepala, kaki dan ekor serta kotorannya) dapat dimanfaatkan untuk berbagai keperluan.

Hasil perhitungan persentase menunjukan bahwa persepsi responden terhadap ternak kelinci apakah bisa di gunakan sebagai usaha diperoleh total skor 71,76 yang berada dalam katagori tinggi dalam sub variable pemasaran dengan interval setuju. sebagian masyarakat yang berternak kelinci di Kecamatan Bluluk setuju bahwa ternak kelinci dapat di gunakan sebagai usaha karena masih jarang masyarakat yang berternak kelinci sehingga menjadi peluang yang baik ke depan.Hal ini sesuai pendapat (Sumadji, 2006) Budidaya kelinci ini merupakan pilihan yang lain untuk menambah penghasilan maupun dapat membuka lapangan pekerjaan baru.

Hasil perhitungan persentase menunjukan bahwa persepsi responden terhadap ternak kelinci apakah bisa membantu ekonomi diperoleh total skor 65,88 yang berada dalam katagori tinggi dalam sub variable pemasaran dengan interval setuju. sebagian masyarakat yang berternak kelinci di Kecamatan Bluluk setuju bahwa ternak kelinci dapat membantu ekonomi.

\subsubsection{Aspek sosial}

Dari aspek sosialnya peternakan kelinci yang ada dilokasi sangat memberi manfaat yang besar seperti membuka lapangan pekerjaan bagi masyarakat yang tidak mempunyai pekerjaan, sehingga hal ini dapat membantu mengurangi tingkat pengangguran dilokasi tersebut.

Tabel 8. Persepsi Responden Mengenai Minat Budidaya dengan Sub Variabel aspek sosial di Kecamatan Bluluk Kabupaten Lamongan.

\begin{tabular}{|c|c|c|}
\hline & Soal kuisoner & $(\%)$ \\
\hline \multirow{2}{*}{$\mathrm{O}$} & lingkungan & 6588 \\
\hline & $\begin{array}{l}\text { Saudara berpengaruh terhadap budidaya } \\
\text { ternak kelinci? }\end{array}$ & \\
\hline & $\begin{array}{l}\text { Apakah kelinci memiliki aspek sosial yang } \\
\text { baik di lingkungan masyarakat? }\end{array}$ & 65,88 \\
\hline & $\begin{array}{l}\text { Apakah bau/aroma dari budidaya ternak } \\
\text { kelinci tidak mengangu masyarakat } \\
\text { sekitar? }\end{array}$ & 70,58 \\
\hline & $\begin{array}{l}\text { Apakah bau menyengat yang di timbul } \\
\text { akibat kotoran dari ternak kelinci tidak } \\
\text { mengangu masyarakat sekitar? }\end{array}$ & 70,58 \\
\hline & $\begin{array}{l}\text { Apakah dengan adanya limbah yang } \\
\text { ditumpuk di sekitar peternak kelinci tidak } \\
\text { mengangu masyarakat sekitar? }\end{array}$ & 67,05 \\
\hline & Rata-rata & 67,99 \\
\hline
\end{tabular}

Sumber : Data Primer Setelah Diolah, (2016)

Berdasarkan Tabel 8. Lampiran 7. Hasil

perhitungan persentase menunjukan bahwa persepsi responden terhadap kondisi lingkungan apakah berpengaruh terhadap budidaya kelinci diperoleh total skor 65,88 yang berada dalam katagori tinggi dalam sub variable pemasaran dengan interval setuju. sebagian masyarakat yang berternak kelinci di Kecamatan Bluluk setuju bahwa lingkungan sangat berpengaruh terhadap ternak kelinci. Hal ini sesuai pendapat (Hustamin Rudy,2006) Sistem perkandangan yang di gunakan harus memperhatikan kemudahan berkerja,penghematan waktu,dan tenaga. Syarat utama untuk membangun kandang adalah dekat dengan sumber air,berada di lokasi yang sejuk (temperature 15-20 C), kelembaban $60-90 \%$, serta jauh dari berbagai ganguan dan predator.

Hasil perhitungan persentase menunjukan bahwa persepsi responden terhadap ternak kelinci apakah memiliki aspek sosial yang baik di masyarakat diperoleh total skor 65,88 yang berada dalam katagori tinggi dalam sub variable pemasaran dengan interval setuju. sebagian masyarakat yang berternak kelinci di Kecamatan Bluluk setuju bahwa lingkungan sangat berpengaruh terhadap ternak kelinci.Hal ini sesuai dengan pendapat (fiqihislam 2012) bahwa salah satu usaha yang digeluti masyarakat adalah usaha peternakan kelinci dengan alasan sebagai pekerjaan sampingan.Sedangkan dari aspek ekonomi dapat dijadikan sebagai pendapatan pokok peternak dan sebagai 
pendapatan tambahan bagi para petani dan pekerja lainnya karna dari beternak kelincipara peternak dapat memperoleh keuntungan dari kelinci yang mempunyai nilai jual yang tinggi.

$$
\text { Hasil perhitungan persentase }
$$

menunjukan bahwa persepsi responden terhadap bau/aroma dari ternak kelinci apakah tidak mengangu masyarakat diperoleh total skor 70,58 yang berada dalam katagori tinggi dalam sub variable pemasaran dengan interval setuju. sebagian masyarakat yang berternak kelinci di Kecamatan Bluluk setuju bahwa bau/aroma tidak mengangu masyarakat. Hal ini sesuai dengan pendapat Kuntoro (2011) bahwa bila limbah ini dikelolah dengan baik dapat memberikan nilai tambah. Salah satu upaya untuk mengurangi limbah adalah mengintegrasikan usaha tersebut dengan beberapa usaha lainnya, seperti penggunaan suplemen pada pakan, usaha pembuatan kompos, budidaya ikan, budidaya padi sawah, sehingga menjadi suatu sistem yang saling sinergis serta Upaya memadukan tanaman, ternak dan ikan di lahan pertanian memiliki manfaat ekologis dan ekonomis.

Hasil perhitungan persentase menunjukan bahwa persepsi responden terhadap bau menyengat yang di timbulkan dari kotoran ternak kelinci tidak mengangu masyarakat sekitar diperoleh total skor 70,58 yang berada dalam katagori tinggi dalam sub variable aspek sosial dengan interval setuju. sebagian masyarakat yang berternak kelinci di Kecamatan Bluluk setuju bahwa bau menyengat tidak mengangu masyarakat sekitar. Hal ini sesuai dengan pendapat Revo (2012) bahwa bau menyengat muncul jika hujan turun, maupun angin kencang.

Hasil perhitungan persentase menunjukan bahwa persepsi responden terhadap limbah yang di tumpuk di sekitar peternak kelinci tidak mengangu masyarakat sekitar diperoleh total skor 67,05 yang berada dalam katagori tinggi dalam sub variable aspek sosial dengan interval setuju. sebagian masyarakat yang berternak kelinci di Kecamatan Bluluk setuju bahwa limbah yang ditumpuk tidak mengangu masyarakat sekitar. Hal ini sesuai dengan pendapat Kuntoro (2011) bahwa bila limbah ini dikelolah dengan baik dapat memberikan nilai tambah. Salah satu upaya untuk mengurangi limbah adalah mengintegrasikan usaha tersebut dengan beberapa usaha lainnya, seperti penggunaan suplemen pada pakan, usaha pembuatan kompos, budidaya ikan, budidaya padi sawah, sehingga menjadi suatu sistem yang saling sinergis serta Upaya memadukan tanaman, ternak dan ikan di lahan pertanian memiliki manfaat ekologis dan ekonomis.

\section{Kesimpulan}

\section{KESIMPULAN DAN SARAN}

Dari hasil dan pembahasan yang telah dikemukakan sebelumnya maka dapat ditarik kesimpulan sebagai berikut:

Berdasarkan hasil dari skala Analisis faktor-faktor yang mempengaruhi minat budidaya ternak kelinci diKecamatan Bluluk Kabupaten Lamongan adalah faktor-faktor yang mempengaruhi minat budidaya ternak kelinci masuk dalam rata-rata sebagai berikut faktor produksi 72,93 pakan dan kandang 73,16 pemasaran 72,23 aspek sosial 67,99. Di peroleh nilai rata-rata tertinggi pada faktor pakan dan kandang 73,16 dengan kisaran antara 60-80\%.

\section{Saran}

Dari kesimpulan di atas penulis menyarankan agar dilakukan penelitian selanjutnya untuk menganalisis faktor-faktor yang mempengaruhi minat peternak dalam budidaya ternak kelinci.

\section{AAK. 1992. Pemeliharaan Kelinci. Kanisius.Yogyakarta.}

Aritonang. 1995. Perencanaan dan Pengelolaan Usaha Babi. Penebar Swadaya. Jakarta.

Arman. 2005. Faktor-Faktor Yang Mempengaruhi Produktivitas Kerja Peternak Sapi Perah Di Kecamatan Sinjai Barat Kabupaten Sinjai. Skripsi. Fakultas Peternakan. Universitas Hasanuddin . Makassar

Bai'ad Muh.Sahlan. 2012.Pengaruh Bobot Badan Pada Fase Grower Terhadap Produksi Telur Saat Ayam Memasuki Fase Layer. Skripsi. Fakultas Peternakan Universitas Hasanuddin. Makassar. 
Bakrie dkk. 2008. Kartadisastra. 1994. Kelinci

Unggul. Kanisius, Yogyakarta.

Blakely dan Bade. 1998. Ilmu Peternakan.

Terjemahan Bambang Srigandana,

Gajah Mada University.

Bakrie, dkk.2008. Analisis Faktor Yang

Mempengaruhi Preferensi Konsumen

Terhadap Produk Peternakan Di

Wilayah Perkotaan DKI Jakarta.

Jurnal. Jakarta: Balai Pengkajian

Teknologi Pertanian Jakarta.

Diwyanto, dkk.1985, Pengaruh Persilangan

Terhadap Karkas dan Prefensi

Daging Kelinci Panggang. Jurnal.

Ilmudan Peternakan.

Fatmawati.2011. Kontribusi Curahan Kerja

Wanita pada Usaha Peternakn

Kelinci di Kelurahan Salokaraja

Lalaban Kabupaten Sopang. Skripsi

Sosial ekonomi Peternakan, Universitas Hasanudin. Makasar.

Fiqih islam.2012. Berternak Kelinci Sebagai Penyedia Lapangan Kerja.

Suaramedia. Jakarta.

Hardjopranjoto. 1995. Ilmu Kemajiran Pada

Ternak. Airlangga University

Hustamin Rudy. 2006. Panduan Memelihara

Ternak Kelinci Hias. Agromedia

Pustaka.

Herawati,dkk. 2013. Preferensi Konsumen

Terhadap Pembelian Telur Ayam Ras

di Kota Mojokerto. Fakultas

Peternakan Universitas Brawijaya.

Malang.

Hustamin. 2006. Panduan Memelihara Kelinci

Hias. Agromedia Pustaka. Jurnal. jakarta.

Bakrie dkk. 2008. Kartadisastra. 1994. Kelinci Unggul. Kanisius, Yogyakarta.

Press,Surabaya. Anonimus.19913. Beternak

Kelinci Secara Populer. Eka Offest. Semarang.

Rismunandar.1990. Meningkatkan Konsumsi Protein dengan Beternak Kelinci. Sinar Baru, Bandung.

Rukman. H. P. 2005.Prospek Berternak Kelinci. http://www. Surabaya Online.com/ news. Diakses Tanggal 2 Februari 2008.

Rismunandar. 1975. Beternak Kelinci Unggul. Masa Baru. Bandung-Jakarta.
Rianggoro 1995.Beternak Kelinci. Karya Anda. Surabaya.

Sarwono. B. 1985. Berternak Kelinci Unggul .Penebar Swadaya. Jakarta.

Sarwono. 2002. Kelinci Potong Dan Hias. Agromedia Pustaka. Jakarta.

Sirajuddin,N. 2004. Analisis Produktivitas Kerja Peternak Pada Usaha Ayam Ras Pedaging Pola Kemitraan dan mandiri Di Kabupaten Maros. Tesis. Universitas Hasanuddin. Makassar.

Sumoprastowo. 1993. Berternak Kelinci Idaman. Bhratara. Jakarta.

Subroto S. 1998. Ayo Berternak Kelinci, CV Aneka Ilmu. Semarang.

Sumadji. 2006. Budidaya Ternak Kelinci. Surabaya.

Singarimbun M. 1989. Metode Proses

Penelitian. Dalam: M. Singarimbun dan

S. Efendi (editor). Metode Penelitian Survai LP3ES. Jakarta.

Sirajuddin,N. 2004. Analisis Produktivitas Kerja Peternak Pada Usaha Ayam Ras Pedaging Pola Kemitraan dan mandiri Di Kabupaten Maros. Tesis. Universitas Hasanuddin. Makassar

Partodihardjo. 1980. Ilmu Reproduksi Hewan. Mutiara. Jakarta.

Pajar.2008. Analisis Faktor-faktor yang Mempengaruhi Produktivitas Kerja Karyawan Bagian Keperawatan pada Rumah Sakit PKU Muhammadiyah Surakarta.Skripsi.Fakultas Ekonomi Manajemen. UMS. Surakarta.

Umar.2000. Metode Penelitian Untuk Skripsi dan Tesis Bisnis. PT. Raja Grafindo Persada. Jakarta.

Whendrato dan Madyana. 1999. Beternak Kelinci Secara Populer. EkaOffest. Semarang. 